\title{
Dispelling disaster myths about dead bodies and disease: the role of scientific evidence and the media
}

\author{
Oliver Morgan ${ }^{1}$ and Claude de Ville de Goyet ${ }^{2}$
}

Suggested citation

Morgan O, de Ville de Goyet C. Dispelling disaster myths about dead bodies and disease: the role of scientific evidence and the media. Rev Panam Salud Publica 2005;18(1):33-6.

\begin{abstract}
For decades, after nearly every natural disaster, fear of disease has encouraged communities, local authorities, and governments to rapidly dispose of the bodies of the victims without first identifying them. In May 2004 this journal published the first-ever review article to comprehensively assess the scientific evidence on the infectious disease risks of dead bodies following natural disasters, along with an editorial commenting on the persistence of myths concerning the dangers allegedly posed by dead bodies. This paper assesses the impact that the review article and the editorial have had on the way that health risks from dead bodies have been reported by the media over the following year, especially focusing on the South Asian tsunami disaster of December 2004. While some media outlets have reported erroneous information, hundreds of other news stories have accurately reported that dead bodies pose no public health risk, and have explained the priority for properly identifying the deceased. Nevertheless, publication of scientific evidence alone is insufficient to bring about public health action. International agencies need to continue their work on producing standards, guidelines, and practical guidance on managing dead bodies. There needs to be a community-centered approach to informing communities about the management of the dead following disasters and the rights of individuals to be treated respectfully after death. Nongovernmental organizations should be encouraged to provide expertise and technical support in identifying and burying large numbers of dead. There also needs to be ongoing assessment of the technical processes involved in the recovery, identification, and disposal of dead bodies, as well as the effectiveness of disaster preparedness plans and communication with the affected population.
\end{abstract}

Key words Cadaver, burial, natural disasters, disease outbreaks, communications media, information dissemination.

For over 20 years we have known that the bodies of those killed in natural disasters do not cause outbreaks

\footnotetext{
${ }^{1}$ London School of Hygiene and Tropical Medicine, London, United Kingdom. Send correspondence to: Oliver Morgan; e-mail: omorgan@bigfoot.com

2 International disaster risk management consultant, Chevy Chase, Maryland, United States of America.
}

of infectious diseases $(1,2)$. However, after nearly every natural disaster, fear of disease encourages communities, local authorities, and governments to rapidly dispose of the bodies of the victims without first identifying them. The consequences of this hasty, unnecessary action include psychological distress for survivors and a lack of proper death certification that leads to legal problems for inheritance, compensation, insurance claims, and remarriage of the spouse. There may also be diplomatic tension when foreign tourists are involved, as in the case of the December 2004 tsunami in Asia. 
There are several reasons for the stubborn popularity of the myth about the dangers from dead bodies. Repulsion to the smell of decay may be part of a primordial "protective mechanism" against disease (3). Many people, including health professionals, also mistakenly extrapolate the disease risks from individuals who die from infectious disease to victims of natural disasters, who instead die from trauma and drowning. These fears tend to be reinforced by journalists, partly because they too are misinformed, but also because the news media tend to gravitate towards the sensational. To successfully challenge these beliefs we must first get the facts straight. However, until recently the lack of scientific evidence to refute these claims has made it difficult to change the attitudes and practices.

In the May 2004 issue of this journal we two authors of this paper published, respectively, a review article assessing the scientific evidence on the infectious disease risks of dead bodies following natural disasters (4) and an accompanying editorial commenting on the persistence of myths concerning the risks allegedly posed by dead bodies (5). For the first time in the peerreviewed scientific literature, these papers outlined a scientific basis to refute the myth that dead bodies cause epidemics after natural disasters. The papers also pointed out two other key facts: (1) that the risk for the public is negligible and (2) that for individuals who have close contact with the dead, the risk of diseases is likely to be small and is easily avoidable. From June 2004 through April 2005 the review article was the item downloaded most frequently-more than 26400 times-from the Publications Web site (http://publications.paho.org) of the Pan American Health Organization (PAHO). In just the two months of December 2004 and January 2005, more than 19000 copies of the article were downloaded (along with over 2200 copies of the editorial), clearly indicating the need for information on this topic after the South Asian tsunami disaster on 26 December 2004.

\section{ENGAGING WITH THE MEDIA}

Following heavy rains in May 2004, flooding in the Dominican Republic and Haiti resulted in about 2000 deaths. Many media outlets reported that rapid mass burials were needed to prevent the spread of infectious diseases, and many victims of the flooding were buried without identification. Press releases issued at the end of May by this journal and by the London School of Hygiene and Tropical Medicine drew the media's attention to our papers and led to news coverage in national newspapers, Internet news services, radio broadcasts, and some medical journals. However, the press releases and the accurate news coverage did not stop some expatriate relief workers from making misinformed, alarmist statements. In September 2004 the Dominican Republic and Haiti were again affected, this time by Hurricane Jeanne. New press releases issued by the London School of Hygiene and Tropical Medicine and by the Pan American Health Organization emphasized the findings published in our two pieces earlier in the year, but little press coverage resulted.

The South Asian tsunami disaster of December 2004 caused the fear of death and disease to hit the headlines once more. Many news agencies reported the need for quick disposal of the dead in order to prevent outbreaks of disease. In India, health professionals described decaying bodies as "bacteria factories" (6) and encouraged their immediate cremation. Mass burials were reported in Sri Lanka, partly due to the logistical difficulties of managing a large number of fatalities, but also from pressure by affected communities. In Indonesia the collection and disposal of tens of thousands of dead bodies in mass graves became a military task. Such was the scale that not even the number of bodies was fully known. In Thailand the initial response was to bury the dead as soon as possible. However, due to the large number of foreign tourists involved, a huge international forensic effort was launched, and many bodies were exhumed.
Ironically, sensational statements contained in a press release issued by the World Health Organization (WHO) on December 30 (7) may have been misconstrued by some media outlets, helping perpetuate the myth about the dangers from dead bodies. That release quoted a WHO official saying that "we could see as many fatalities from diseases as we have seen from the actual disaster itself." For its part, $\mathrm{PAHO}$ issued a press release on December 29 that was headlined "Fears of dead bodies are unfounded" (8). The PAHO press release, along with media interviews with PAHO and WHO staff members and a WHO information sheet on communicable disease risks after flooding $(9,10)$ that drew heavily on the earlier review article in this journal (4) led to hundreds of news stories that accurately reported that dead bodies posed no public health risk and that explained the priority for properly identifying the deceased.

\section{PUTTING SCIENCE INTO PRACTICE}

Our two papers published last year in this journal and the WHO information sheet have undoubtedly reduced much of the misinformation about dead bodies. Nevertheless, publication of scientific evidence is alone insufficient to bring about public health action. Achieving permanent change in public health practice requires a variety of strategies. One strategy, where WHO and PAHO excel, is the topdown approach of producing standards and guidelines. For example, in late 2004 PAHO published a book on the management of dead bodies in disaster situations (11). While that book makes a valuable public health contribution, it does little to help the unprepared authorities to deal practically with the overwhelming logistical challenge presented by hundreds or thousands of bodies. To address this gap, PAHO organized a workshop of international disaster and forensic specialists in Lima, Peru, on 16 and 17 May 
2005. The workshop focused on lessons learned from the South Asian tsunami disaster and practical measures for first responders after natural disasters. The outcomes of this meeting will include a practical field manual for the management of dead bodies as well as an updated edition of PAHO's 2004 book on dead bodies and disasters.

That strategy of producing standards and guidelines is not the only one needed in order to bring about changes in attitudes and practices. A second one that we should consider is a community-centered approach that informs communities about the management of the dead following disasters, and the rights of individuals to be treated respectfully after death. This is likely to require continued proactive engagement with the media in the way that PAHO has recently been doing. Thirdly, an educational approach is needed to develop workshops and table-top exercises as part of disaster preparedness activities and capacity development within governments misibles y la vigilancia epidemiológica en situaciones de desastres naturales. Bol Oficina Sanit Panam. 1980;89(4):353-69.

2. De Ville de Goyet C. Stop propagating disaster myths. Lancet. 2000;356:762-4.

3. Curtis V, Biran A. Dirt, disgust, and disease. Is hygiene in our genes? Perspect Biol Med. 2001:44(1):17-31.

4. Morgan O. Infectious disease risks from dead bodies following natural disasters. Rev Panam Salud Publica. 2004;15(5):307-12.

5. De Ville de Goyet C. Epidemics caused by dead bodies: a disaster myth that does not want to die. Rev Panam Salud Publica. 2004; 15(5):297-9.

6. NBC11.com. Threat of health epidemic looms after quake, tsunamis [news report]. Available from: http://www.nbc11.com/health/ 4029138/detail.html. Accessed 21 January 2005. and, perhaps above all, with humanitarian organizations. Fourthly, identifying and burying large numbers of dead is a difficult task, requiring significant international expertise and technical support. Although no agency currently provides this type of support, it could be encouraged as an area of technical cooperation for nongovernmental organizations (NGOs). Some NGOs, such as the Red Cross, arrive very quickly on the scene, and, if equipped with appropriate skills and resources, could contribute to the identification of the dead. Unfortunately, at a time of increasing specialization of humanitarian NGOs, it is an area often overlooked. Finally, we need to continue adding to existing theoretical knowledge by developing audit and feedback activities about the management of dead bodies following natural disasters. These should focus not only on technical processes (recovery, identification, and disposal of dead bodies), but also consider the effectiveness of disaster preparedness

\section{REFERENCES}

7. World Health Organization. WHO warns up to five million people without access to basic services in Southeast Asia [press release]. Available from: http://www.who.int/ mediacentre/news/releases/2004/pr94/en/ Accessed 3 March 2005.

8. Pan American Health Organization. Fears of dead bodies are unfounded [press release]. Available from: http://www.paho.org/ English/DD/PIN/pr041229.htm Accessed 29 January 2005.

9. Jones M. How good was tsunami coverage in the media? [news story]. Available from: http://www.alertnet.org/thefacts/ reliefresources/110667336256.htm Accessed 29 January 2005.

10. World Health Organization. Flooding and communicable diseases fact sheet [Web page]. Available from: http://www.who.int/ hac/techguidance/ems/en/Floodingand plans and communication with the affected population.

\section{CONCLUSION}

Until recently the management of the dead after natural disasters has been informed by a mistaken imperative to prevent the spread of disease and the need to appease public fears of epidemics, which are often fueled by the media. To ensure the well-being of the survivors, the dead should be treated with dignity and respect. Managing the dead involves complex technical and logistical considerations, but it also has a significant social and cultural dimension, which is reflected and formed by the media. It is therefore crucial that, in addition to developing our knowledge about how to manage the dead after natural disasters, we develop strategies to engage the media and promote the rights of the survivors to see that their dead are treated with dignity and respect.
CommunicableDiseasesfactsheet.pdf 2004. Accessed 27 December 2004.

11. Pan American Health Organization. Management of dead bodies in disaster situations. Washington, D.C.: PAHO; 2004. (Disaster Manuals and Guidelines on Disasters Series, No. 5).

Manuscript received 10 March 2005. Manuscript accepted for publication 23 March 2005. 
RESUMEN A lo largo de varios decenios se ha visto que, a raíz de casi todos los desastres naturales, el temor a la propagación de enfermedades ha llevado a las comunidades, autoridades locales y gobiernos a disponer con rapidez de los cadáveres de las víctimas,

\section{Se despejan los mitos sobre la relación de los cadáveres con las enfermedades en situaciones de desastre: el papel de las pruebas científicas y de los medios de comunicación}

Palabras clave sin llegar a identificarlas. En mayo de 2004 se publicó en esta revista el primer artículo de revisión que jamás haya examinado en su conjunto todas las pruebas científicas existentes sobre la presunta relación entre la propagación de enfermedades infecciosas y los cadáveres después de desastres naturales, más un comentario editorial sobre los mitos que perduran al respecto. En este trabajo se evalúa la influencia del artículo de revisión y del editorial sobre la manera en que los noticieros han descrito, en el año transcurrido desde su publicación, los riesgos sanitarios asociados con los cadáveres, particularmente a raíz del maremoto en el sudeste asiático en diciembre de 2004. Aunque algunos noticieros han dado información equivocada, en centenares de reportajes se ha explicado, como corresponde, que los cadáveres no plantean peligro alguno para la salud pública y que poder identificar a las víctimas tiene una importancia prioritaria. No obstante, publicar pruebas científicas no suele ser suficiente para que se tomen las medidas adecuadas. Las agencias internacionales tienen que seguir elaborando normas y lineamientos y ofreciendo orientación práctica sobre el manejo de los cadáveres. Además, hace falta un enfoque comunitario para transmitirles a las comunidades información acerca de lo que se debe hacer con los cadáveres después de un desastre y del derecho de las personas a ser tratadas respetuosamente después de morir. Es importante que las organizaciones no gubernamentales aporten sus conocimientos y apoyo técnico para identificar y enterrar a los muertos cuando son numerosos. También es necesario evaluar de manera continua los procesos técnicos implícitos en la recuperación, identificación y eliminación de los cadáveres, así como la eficacia de los planes de respuesta a situaciones de desastre y las comunicaciones con la población afectada.

Cadáver, entierro, desastres naturales, brotes de enfermedades, medios de comunicación, diseminación de la información.

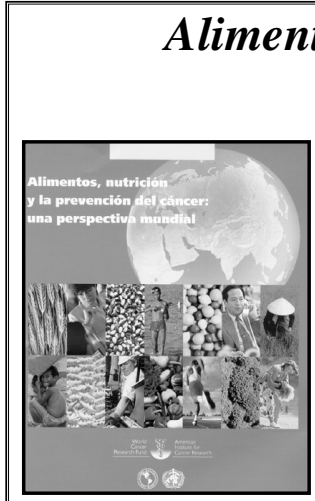

\section{Alimentos, nutrición y la prevención del cáncer: una perspectiva mundial}

Este libro se refiere explícitamente a la prevención primaria del cáncer desde una perspectiva mundial. Se subrayan los aspectos de la alimentación y la nutrición que probablemente reduzcan el riesgo de cáncer, y se resaltan los que podrían incrementar ese riesgo.

Esta publicación se puede adquirir en formato electrónico por medio de Ingenta Connect:

* Visite el sitio: http://www.ingentaconnect.com

* Seleccione "Pan American Health Organization" en la opción Browse publications

* Seleccione cualquiera de los títulos ofrecidos.
} 